\title{
1
}

Tomasz P. Czapla

Uniwersytet Łódzki

http://dx.doi.org/10.18778/8088-905-7.02

\section{Kompetencje uniwersalne jako odpowiedź na potrzeby rynku pracy}

\section{Zmiany regulacji prawnych jako szansa lepszego dostosowania programów kształcenia do potrzeb rynku pracy}

Zgodnie z przyjętym 23 kwietnia 2008 r. zaleceniem Parlamentu Europejskiego i Rady Europy, zostało rozpoczęte wdrażanie europejskich kwalifikacji. Proces ten był realizowany etapami, począwszy od powiązania krajowych systemów edukacji z europejskimi ramami kwalifikacji za pośrednictwem Krajowych Ram Kwalifikacji (KRK). Aktualnie wdrażana jest Polska Rama Kwalifikacji (PRK) - opracowuje się i ogłasza tzw. raporty referencyjne, czyli opisy krajowych systemów kwalifikacji z zastosowaniem metody właściwej dla ram kwalifikacji i jasnym odniesieniem poziomów kwalifikacji krajowych do poziomów Europejskich Ram Kwalifikacji (ERK). Kolejny etap to wdrożenie wymogu umieszczania na dyplomach i świadectwach poświadczających uzyskane kwalifikacje odniesienia do stosownego poziomu KRK i ERK. Zalecenie to było logiczną konsekwencją realizacji Deklaracji Bolońskiej, która podpisana 
została 19 czerwca 1999 r. i stała się podstawą tzw. procesu bolońskiego. Dokument ten podpisali ministrowie odpowiedzialni za szkolnictwo wyższe w Austrii, Belgii, Czechach, Bułgarii, Estonii, Danii, Francji, Finlandii, Grecji, Hiszpanii, Irlandii, Islandii, na Łotwie, w Luksemburgu, na Litwie, w Holandii, na Malcie, w Niemczech, Norwegii, Polsce, Portugalii, Rosji, Rumunii, Słowenii, Słowacji, Szwajcarii, Szwecji, Wielkiej Brytanii, na Węgrzech oraz we Włoszech.

Deklaracja Bolońska zawierała wytyczne dotyczące zasad projektowania programów kształcenia. Do najważniejszych zaliczyć można przejście od nauczania do uczenia się. By zrealizować tę zasadę, należy w większym stopniu uwzględniać $\mathrm{w}$ programach nauczania nakład pracy własnej studenta. Postulat taki odwołuje się wprost do najgłębszego sensu studiowania, będącego świadomym i samodzielnym nabywaniem wiedzy $\mathrm{w}$ procesach poznania i rozumienia. Technicznym narzędziem pomiaru stopnia realizacji tego postulatu stał się Europejski System Transferu Punktów (ang. European Credit Transfer System - ECTS). W rezultacie punkty ECTS, przy pisywane poszczególnym przedmiotom, miały odzwierciedlać to, co się dzieje w trakcie zajęć, przede wszystkim jednak miały wskazywać, ile samodzielnej pracy (studiowania) wymagane jest od studenta.

Kolejną fundamentalną wytyczną zawartą w Deklaracji Bolońskiej jest postulat odejścia od treści programowych w stronę efektów kształcenia. Wdrożenie tej wytycznej wymagało zmiany filozofii projektowania programów kształcenia, co szerzej omówione zostało $\mathrm{w}$ dalszej części rozdziału. Technicznie zaś postulat ten sprowadzał się do wymogu, by każdy przedmiot był definiowany przez efekty kształcenia, a treści programowe były dobierane tak, aby zapewniać osiąganie założonych efektów.

Z punktu widzenia wymogów rynku pracy kluczową wytyczną stał się postulat przejścia od zawodowości do zatrudnialności. Realizacja tego postulatu wymagała zmiany sposobu myślenia o treściach przedmiotów realizowanych $\mathrm{w}$ ramach programów kształcenia. W miejsce myślenia w kategoriach „,co?” - czego uczę (jakiego zawodu), postulowane było wdrożenie myślenia „po co?" - co absolwent będzie mógł robić, jaki za- 
wód wykonywać. $W$ efekcie projektanci programów kształcenia zmuszeni zostali do zweryfikowania, w jakim zakresie oferowane przez programy treści kształcenia gwarantują zatrudnienie studentom zdobywającym kompetencje niezbędne do wykonywania określonego zawodu.

\section{Efekty kształcenia jako podstawa budowania synergii z potrzebami rynku pracy}

Z punktu widzenia rynku pracy przyjęcie wymogu definiowania efektów kształcenia jako rezultatów realizacji treści poszczególnych przedmiotów stanowiło bardzo dobry punkt wyjścia do zunifikowania języka, jakim posługują się uczelnie i pracodawcy, opisując absolwenta i kandydata do pracy. Wychodząc od klasycznego rozumienia kompetencji pracownika jako konglomeratu trzech składowych - wiedzy, umiejętności i postaw - można zauważyć wyraźną zbieżność z trzema kategoriami efektów kształcenia - efektami w zakresie wiedzy, umiejętności oraz kompetencji społecznych ${ }^{1}$. Takie podejście do definiowania efektów kształcenia stanowi potencjalną bazę budowania swoistego efektu synergii między tym, co oferuje uczelnia w postaci efektów kształcenia i tym, czego potrzebują pracodawcy (rys. 1.1).

Jednakże $\mathrm{w}$ budowaniu tego efektu synergii uczelnie napotkały szereg barier - głównie mentalnych. Pierwszą stała się przejrzystość systemu. Potencjalnie jasny przekaz, dotyczący postulatu kształtowania u studenta trzech kategorii efektów kształcenia, postrzegany był jako technokratyczny moloch nie dodający wartości procesowi kształcenia. Środowisko akademickie w dużym stopniu potraktowało efekty kształcenia jako biurokratyczną

${ }^{1}$ W jednej z pierwotnych wersji projektu Krajowych Ram Kwalifikacji pojawiły się efekty w zakresie postaw. Jednakże w późniejszych wersjach dokumentu i w jego wersji ostatecznej zapis ten zastąpiony został znacznie mniej spójnym i logicznym zapisem, dotyczącym kształtowania kompetencji społecznych. Nielogiczność takiego działania wzmacnia także fakt, że wciąż w definicjach kompetencji społecznych znajdują się de facto opisy oczekiwanych postaw. 
nowomowę i miast skupić się na ich sensie i logice, skoncentrowało się na swoistej i potencjalnie uciążliwej „,arytmetyce” efektów kształcenia. Efekty przedmiotowe mają się równać efektom kierunkowym (rozumianym jako suma efektów kierunkowych odpowiadających efektom obszarowym), które opisane zostały w KRK oraz specyficznym efektom kierunkowym, odzwierciedlającym indywidualny charakter kształcenia w danym programie. Obowiązuje zasada, że suma efektów kierunkowych musi być co najmniej równa liczbie efektów obszarowych (rys. 1.2).

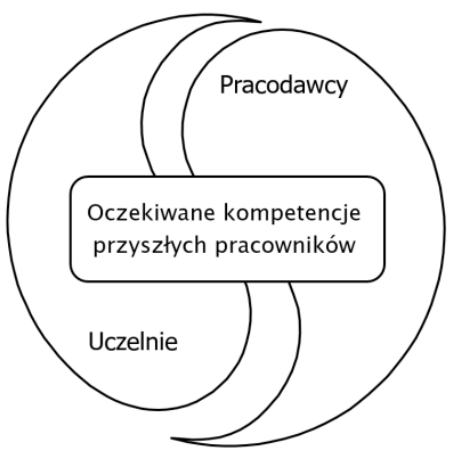

Rysunek 1.1. Synergia między efektami kształcenia a oczekiwaniami pracodawców

Źródło: opracowanie własne

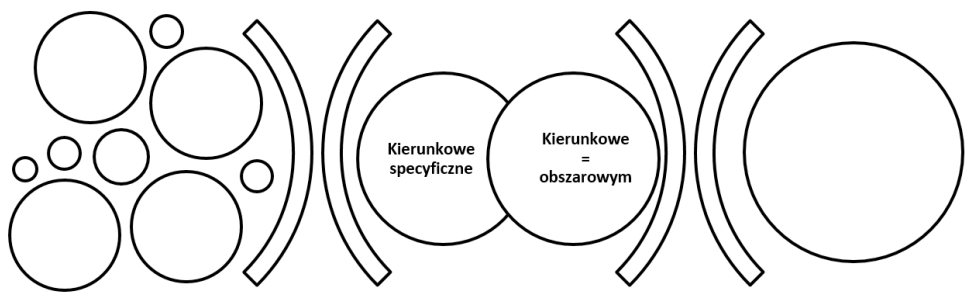

Efekty przedmiotowe $=$ Efekty kierunkowe $\geq$ Efekty obszarowe

Rysunek 1.2. „Arytmetyka” efektów kształcenia Źródło: opracowanie własne 
W praktyce dopisywanie do programów kształcenia jego efektów było często właśnie jedynie dopisywaniem i nie łączyło się ze zmianą podejścia czy wręcz filozofii ich kształtowania. Wciąż treści przedmiotów w większym stopniu odzwierciedlały to, co student ma zapamiętać, a nie to, czego ma się nauczyć. Rola nauczyciela pozostawała niezmienna, lokując go jako tego, który ma przekazywać wiedzę i ją egzekwować, a nie tego, który powinien pomagać tę wiedzę zrozumieć, rozwijać umiejętności (stawiając zadania pomagające je rozwinąć) oraz kreować kompetencje społeczne (kształtując oczekiwane postawy).

\section{Oczekiwania względem absolwentów ze strony pracodawców}

Uwzględnianie zatrudnialności absolwenta powinno być traktowane jako element misji uczelni i jej społecznej odpowiedzialności. Często pojawiają się głosy, że „uczelnia wyższa nie jest (nie może być) wyższą szkołą zawodową". To prawda, jednak postulaty szerszego, bardziej humanistycznego kształcenia absolwentów nie powinny eliminować potrzeby odpowiedzi na pytanie, co nasz absolwent będzie robił po studiach, do robienia czego przygotowujemy go, a w efekcie do rozstrzygania, jakie jego kompetencje kształtujemy.

Gdy zapytać przedstawicieli pracodawców, jak postrzegaja edukację wyższa, w jakim stopniu absolwenci wchodzący na rynek pracy spełniają ich oczekiwania, okazałoby się, że wiele obszarów wymaga jeszcze usprawnienia. Pracodawcy ${ }^{2}$ najwyżej oceniają poziom wiedzy - zapamiętywanych definicji i formuł - jednocześnie podkreślając, że ten aspekt jest dla nich najmniej użyteczny. Słabo rozwijane są umiejętności praktyczne absolwentów - często też dotyczą one obszarów, które nie są oczekiwane przez pracodawców.

${ }^{2}$ Powyższe wnioski są podsumowaniem panelu dyskusyjnego z udziałem przedstawicieli pracodawców takich jak: PwC, E\&Y, KPMG, Skanska. Panel odbył się 12 czerwca 2014 r. na Wydziale Zarządzania UŁ w ramach obchodów 20-lecia Wydziału. 
Zwracają uwagę, że próby rozwijania specyficznych, szczegółowych umiejętności, oczekiwanych na rynku, rozbijają się o czas kształcenia (minimum trzy lata na pierwszym stopniu i minimum dwa 2 lata na drugim stopniu kształcenia). W efekcie uczelnie bywają mało skuteczne $\mathrm{w}$ "produkowaniu” absolwentów na zamówienie rynku, w szczególności, gdy nie można pozwolić sobie na czekanie na "gotowego" absolwenta. Dostrzegają też niedostatki włączania w proces kształcenia elementów pozwalających na lepsze zrozumienie specyfiki funkcjonowania firm $w$ zależności od charakteru działalności, np. zróżnicowanie firm w branży FMCG, firm farmaceutycznych czy operatorów logistycznych.

W efekcie pracodawcy podkreślaja, że przede wszystkim oczekują rozwijania elementarnych, uniwersalnych kompetencji absolwentów, takich jak: umiejętności analityczne, organizowanie pracy własnej, zarządzanie czasem, podejmowanie decyzji. Kompetencje te postrzegają jako swoistą bazę - tworzywo, z którego budują właściwy dla danej firmy, oczekiwany profil kompetencji pracownika. Jak podkreślają umiejętności zawodowe nabywane są i tak w środowisku pracy, na bieżąco i w aktualnie wymaganym zakresie. Jednocześnie pracodawcy oczekuja, by absolwent rozumiał biznes i specyfikę poszczególnych branż. Takie ukształtowanie kompetencji czyniłoby go w oczach prawodawców bardziej atrakcyjnym i wyraźnie skracałoby czas jego adaptacji w firmie, ponadto zmniejszałoby koszty z tym związane.

W niewystarczającym stopniu, w ramach procesu edukacji, rozwijane są oczekiwane postawy, takie jak: przedsiębiorczość, proaktywność, chęć ciągłego (i cierpliwego) rozwoju.

Badania systemów kompetencyjnych ${ }^{3}$, wdrażanych w firmach, pozwalają zidentyfikować oczekiwany przez pracodawców zestaw kompetencji uniwersalnych jako tych, które najpowszechniej są przez nich wykorzystywane. Do grupy kompetencji uniwersalnych można zaliczyć:

- efektywne komunikowanie się, rozumiane jako kompetencja pozwalająca pracownikowi skutecznie funkcjonować w środowi-

${ }^{3}$ Prezentowane zestawienie opracowane zostało na podstawie badania systemów kompetencyjnych 33 firm, które prowadząc działalność na terenie Polski wdrożyły system kompetencji. Por. Czapla (2011: 95-104). 
sku pracy poprzez właściwe, ustne i pisemne, porozumiewanie się - przyjmowanie i przekazywanie informacji oraz ich wyjaśnianie;

- wspótpracę w zespole, czyli kompetencję pozwalającą pracownikowi efektywnie i sprawnie wykonywać działania w warunkach współpracy z innymi pracownikami poprzez konstruktywne uczestniczenie w pracach zespołu;

- innowacyjność, rozumiana jako kompetencja pozwalająca pracownikowi na nieszablonowe, twórcze podejście do wykonywania powierzonych zadań poprzez modyfikowanie aktualnych i znajdowanie nowych, bardziej efektywnych i gwarantujących jakość, sposobów działania;

- nastawienie biznesowe - przedsiębiorczość, rozumiane jako kompetencja pozwalająca pracownikowi na skuteczne i efektywne realizowanie zadań poprzez zrozumienie podstawowych zasad i reguł rynkowych oraz przy ekonomicznym wykorzystaniu zasobów pracy, z zachowaniem oczekiwanego poziomu wskaźników biznesowych;

- planowanie i organizowanie pracy własnej - kompetencja pozwalająca pracownikowi na trafne rozpoznawanie priorytetów i planowanie pracy, tak, by w sposób ekonomiczny (oszczędnie gospodarując wykorzystywanymi zasobami - narzędzia, maszyny, surowce, materiały, itp.), skuteczny (osiągając zamierzone cele) oraz rzetelny i skrupulatny (dbając o standardy bezpieczeństwa i jakość wykonania) realizować powierzone zadania;

- umiejetne podejmowanie decyzji, pozwalające pracownikowi na skuteczne radzenie sobie z sytuacjami decyzyjnymi poprzez właściwe rozpoznawanie dostępnych alternatyw decyzyjnych i dokonywanie najlepszych wyborów;

- analizowanie danych oraz informacji, czyli rozumienie, przetwarzanie danych oraz informacji (ilościowo i jakościowo), wyciąganie na tej podstawie logicznych wniosków;

- stosowanie techniki i technologii - rozumiane jako kompetencja lub zbiór kompetencji ${ }^{4}$ ukierunkowanych na projektowanie

${ }^{4} \mathrm{~W}$ badanych systemach kompetencyjnych pojawiły się dwa podejścia do lokowania w nich kompetencji technicznych. W pierwszym podejściu kompetencje techniczne traktowane były indywidualnie, tzn. wchodziły do systemów 
i/lub stosowanie narzędzi i rozwiązań z zakresu techniki i technologii wykorzystywanej w środowisku pracy.

Wśród najczęściej pojawiających się kompetencji technicznych znalazły się takie jak: posługiwanie się językami obcymi, obsługiwanie komputera, wykorzystywanie umiejętności handlowych, logistycznych i marketingowych, wykorzystywanie narzędzi rachunkowości zarządczej czy stosowanie systemów jakości.

\section{Kompetencje uniwersalne jako podstawa projektowania programów kształcenia}

Drugą barierą w budowaniu wspomnianego wyżej efektu synergii między efektami kształcenia a oczekiwanymi na rynku pracy kompetencjami, jest tradycyjne - silosowe podejście do projektowania programów kształcenia. Podejście takie wywodzi się z koncepcji mistrza w nauczaniu. To mistrz-projektant decyduje, jakie szczegółowe treści znajdą się w przedmiocie. Tak projektowane przedmioty tworzą spójną i logiczną całość, jednocześnie kreują swoiste silosy wiedzy - oddzielone, często nie łączące się z innymi "całościami”, fragmenty wiedzy budujące poznanie, ale często nie budujące zrozumienia (w szczególności, gdy odniesiemy to rozumienie do perspektywy szerszego kontekstu, np. zjawisk organizacyjnych). Logikę tak projektowanych programów kształcenia przedstawiono na rys. 1.3.

Tradycyjne podejście do projektowania programów kształcenia obarczone jest ryzykiem powtórzeń $\mathrm{w}$ zakresie oferowanych treści, a to, czy program tworzy logiczną i spójną całość jest wynikiem swoistego kompromisu, który z kolei stanowi pochod-

pod szczegółowymi nawami (patrz przykłady powyżej). W drugim podejściu kompetencje techniczne traktowane były uniwersalnie jako umowna (uniwersalna) kompetencja, odnosząca się do stosowania techniki i technologii w środowisku pracy. Najczęściej stosowaną nazwą tak rozumianej kompetencji technicznej była biegłość zawodowa. Rozwiązanie takie stosowano w co piątym badanym systemie kompetencji. 
ną otwartości, chęci komunikacji i elastyczności poszczególnych osób odpowiedzialnych za projektowanie szczegółowych treści przedmiotów.
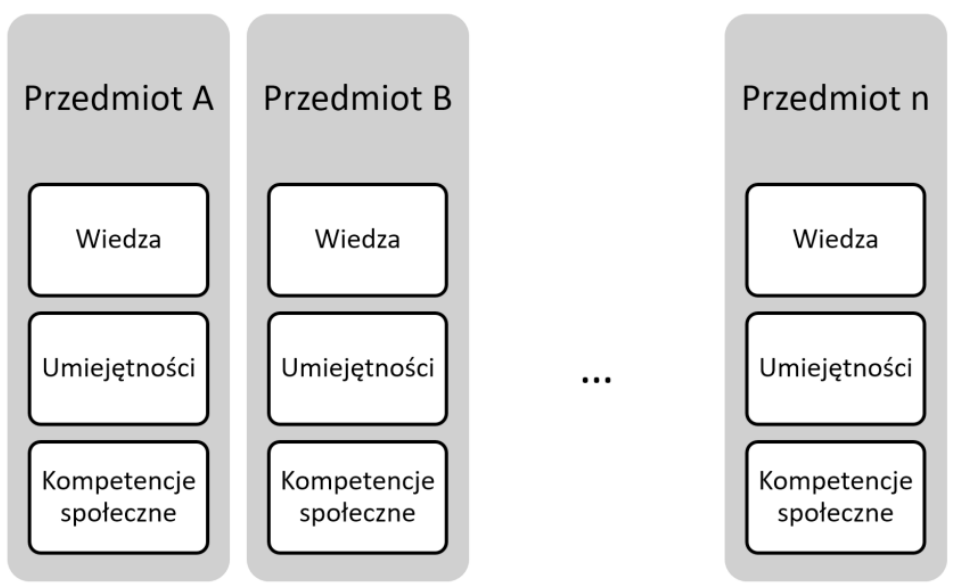

Rysunek 1.3. Tradycyjne podejście do projektowania programów kształcenia Źródło: opracowanie własne

Przyjmując jako punkt wyjścia w projektowaniu programów kształcenia oczekiwania rynku pracy, należałoby znacząco zmienić stosowaną tu filozofię. Punktem wyjścia powinien być zestaw kompetencji uniwersalnych, który jest wykorzystywany i oczekiwany przez rynek pracy. Następnie uczelnie powinny dokonać swoistego mapowania, przekładając kompetencje uniwersalne na efekty kształcenia. Największą zmianą w filozofii projektowania programów kształcenia jest tu odejście od projektowania treści poszczególnych przedmiotów jako samodzielnych całości w stronę projektowania treści przedmiotów jako nośników kompetencji. Treści przedmiotów w takim podejściu powinny umożliwiać stosowanie poszczególnych kompetencji. Posługując się alegoria, zestaw kompetencji uniwersalnych przyrównać można do zestawu uniwersalnych kluczy, za pomocą których rozwiązujemy wciąż nowe problemy, opisywane treściami przedmiotów. W takim podejściu na pierwszy plan wychodzi rozumienie, 
a poznanie staje się logiczną konsekwencją zwiększania sprawności rozumienia tego fragmentu rzeczywistości, któremu dedykowany jest dany program kształcenia. Logikę tak projektowanych programów kształcenia zaprezentowano w formie rys. 1.4.

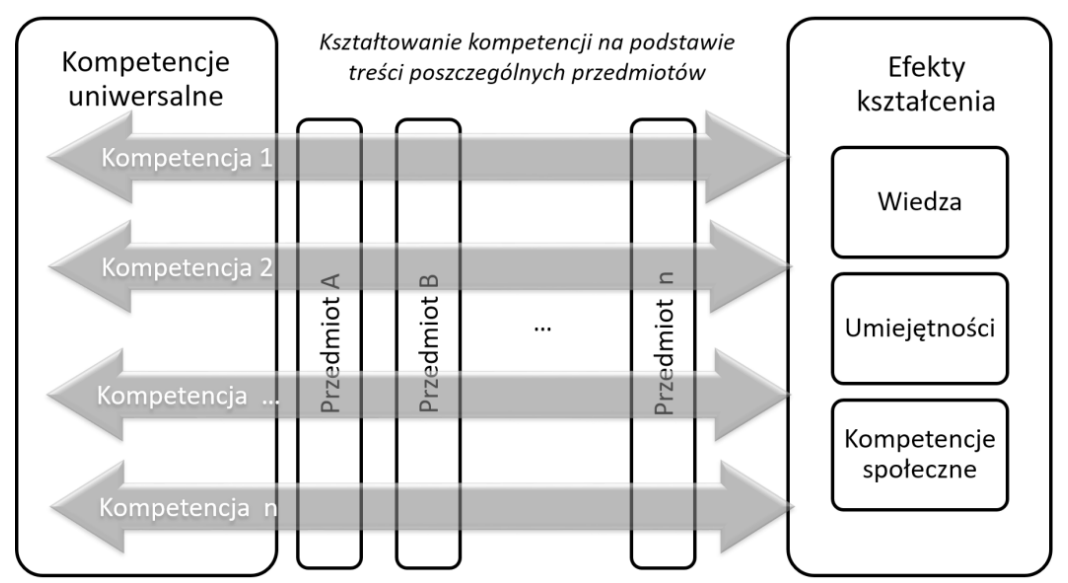

Rysunek 1.4. Tradycyjne podejście do projektowania programów kształcenia Źródło: opracowanie własne

Ponieważ w podejściu tym punktem wyjścia są kompetencje uniwersalne, można odnieść wrażenie, że ma ono zastosowanie jedynie w odniesieniu do programów kształcenia, projektowanych na kierunkach ekonomicznych. Nic bardziej błędnego. Kompetencje uniwersalne mogą być wykorzystywane i kształtowane w szerokim spektrum treści, w ramach przedmiotów dedykowanych humanistyce, sztuce i w naukach ścisłych. W efekcie podejście to ma walor uniwersalny i może być powszechnie implementowane do projektowania programów kształcenia.

\section{Literatura}

Czapla T. (2011), Modelowanie kompetencji pracowniczych w organizacji, Wydawnictwo Uniwersytetu Łódzkiego, Łódź. 